\title{
Knowledge, Attitude, Perceptions and Practice towards COVID-19: A systematic review and Meta-analysis
}

\author{
Akshaya Srikanth Bhagavathula ${ }^{1}$, Wafa Ali Aldhaleei ${ }^{2}$, Jamal Rahmani $^{3}$, Jagdish \\ Khubchandani ${ }^{4}$
}

${ }^{1} \mathrm{Ph} . \mathrm{D}$ student, Institute of Public Health, College of Medicine and Health Sciences, United Arab Emirates University, Al Ain, UAE. Email: akshaypharmd@ gmail.com

${ }^{2}$ Gastroenterology Fellow, Department of Gastroenterology, Sheikh Shakhbout Medical City, Abu Dhabi, UAE. Email: wafa.ali.aldhaleei@gmail.com

${ }^{3}$ Ph.D student, Department of Community Nutrition, Faculty of Nutrition and Food Technology, Shahid Beheshti University of Medical Sciences, Tehran, Iran. Email: jrahmani@sbmu.ac.ir

${ }^{4}$ Professor of Health Science, Department of Nutrition and Health Science, College of Health, Ball State University, Indiana, USA. Email: jkhubchandan@bsu.edu

\section{Corresponding author}

Dr. Akshaya Srikanth Bhagavathula, PharmD, PhD student, Institute of Public Health, College of Medicine and Health Sciences,

UAE University, Al Ain, UAE Email: akshaypharmd@gmail.com

Phone: +971-543226187 
medRxiv preprint doi: https://doi.org/10.1101/2020.06.24.20138891; this version posted June 24, 2020. The copyright holder for this preprint (which was not certified by peer review) is the author/funder, who has granted medRxiv a license to display the preprint in perpetuity.

It is made available under a CC-BY-NC-ND 4.0 International license .

\begin{abstract}
Background: Several studies among various population groups have been conducted to investigate the level of knowledge, attitudes, perceptions, and risk reduction practices (KAP) related to COVID-19. A comprehensive review on this topic is important to highlight the areas for improvement and interventions to prevent COVID-19. Thus, the purpose of this study was to summarize the level of KAP about COVID-19 via a systematic review

Methods: A systematic literature search was performed using a combination of selected keywords in four scientific databases to identify relevant literature published from January 1 to May 31, 2020. Nineteen articles were included in the systematic review, and sixteen studies in the meta-analysis. The data was analyzed using a random-effects model due to the heterogeneity between the studies.

Results: Lack of COVID-19-related knowledge, positive perceptions, and preventive practices were detected and seems widespread. In particular, 56.6\% (95\%CI: 45.9-67\%) of the health care workers (HCWs) and medical students had poor knowledge about COVID-19 and only $46 \%$ (95\% CI: 15-77) of the total study sample had positive perceptions towards COVID-19. Besides, $81.7 \%$ of the sample prioritized practicing hand hygiene to prevent COVID-19, but wearing a face mask to prevent COVID-19 transmission was suboptimal (73.4\%). Finally, around eighty percent of the subjects had good knowledge about COVID19 symptoms $(79 \%)$ and its transmission $(82 \%)$ and reported that they avoided crowded places to prevent getting COVID-19 (89\%).

Conclusion: Evidence-based practices on risk communication and raising awareness should be planned by local governments in collaboration with healthcare organizations. Specifically, educational initiatives for $\mathrm{HCW}$ s to prioritize wearing a face mask and practicing hand hygiene should be considered a priority.
\end{abstract}

Keywords: knowledge; attitude; practice; Coronavirus; meta-analysis; hygiene; hand wash; mask; prevention 
medRxiv preprint doi: https://doi.org/10.1101/2020.06.24.20138891; this version posted June 24, 2020. The copyright holder for this preprint (which was not certified by peer review) is the author/funder, who has granted medRxiv a license to display the preprint in perpetuity.

It is made available under a CC-BY-NC-ND 4.0 International license .

\section{Introduction}

The novel coronavirus (COVID-19) pandemic is a global health concern approaching 10 million cases by the end of June 2020 [1]. COVID-19 infection is highly transmissible causing profound social, economic, and political upheaval worldwide. So far, no antiviral drugs or vaccines are available explicitly to prevent or cure COVID-19 infection. Absent such measures, applying preventive strategies to control the infection are of paramount importance. Since the origin of COVID-19 in China, several measures were deployed by governments and public health organizations worldwide to raise awareness, improve knowledge, and to strengthen the preventive measures to control COVID-19 transmission [24]. However, lack of knowledge about COVID-19 transmission, inadequate understanding of the population at risk, and not paying attention to preventive measures are still widespread among regions and populations [5-8]. As a result, COVID-19 infections continue to spread and cause profound morbidity and mortality around the world. Several studies among various population groups across regions have been conducted to investigate the level of knowledge, attitudes, perceptions, and risk reduction practices as it relates to the prevention of COVID19 transmission (KAP) [9-27]. Despite these studies, in a comprehensive review of literature, we could not find a systematic review summarizing global KAP on COVID-19 prevention practices. In the absence of such an evidence synthesis review, gaps in KAP, and COVID-19 prevention practices around the world cannot be identified. In addition, such reviews are critical to provide empirical evidence on interventions and strategies that can be implemented for COVID-19 prevention among various populations. Thus, the purpose of this study was to conduct a systematic review and meta-analysis to summarize KAP on COVID-19 and to highlight areas for required interventions and evidence-based practices to prevent COVID-19. 
medRxiv preprint doi: https://doi.org/10.1101/2020.06.24.20138891; this version posted June 24, 2020. The copyright holder for this preprint (which was not certified by peer review) is the author/funder, who has granted medRxiv a license to display the preprint in perpetuity.

It is made available under a CC-BY-NC-ND 4.0 International license .

\section{Methods}

Strategy

A systematic review and meta-analysis on KAP about COVID-19 following the Preferred Reporting Items for Systematic Review and Meta-Analysis (PRISMA) guidelines was conducted [28]. Cross-sectional observational studies investigating the knowledge, attitude, perceptions, and practice about COVID-19 and published from January - May 31, 2020, were included in our analysis.

\section{Literature Search}

A literature search was conducted using MeSH keywords in four databases of peer-reviewed publications (PubMed, Scopus, Embase, and Google scholar). The following keywords were used: knowledge* OR attitude* OR perception* OR belief* OR practice*, AND crosssectional studies*, AND questionnaire*, AND surveys*, AND observational* AND coronavirus* OR coronavirus infections*, OR novel coronavirus* OR covid-19*, OR severe acute respiratory syndrome* OR coronavirus disease* AND physicians* OR doctors* OR primary care* OR dentists* OR dental* OR nurses* OR nursing* OR community health workers* OR public health nursing* OR health professionals* OR public health* OR pharmacy* OR students* OR *general public OR population* OR community*. The field was limited to "title/abstract," and the publication type was limited to "journal article" and "pre-prints" published in the English language. Letter to editors, case reports, study protocols, reviews, and interventional studies were not included in this study. The reference list of articles found in our search were also reviewed to identify other articles. We limited our review to the studies that used a structured questionnaire administered among different population assessing the following:

- Knowledge: COVID-19 symptoms

- Knowledge: COVID-19 transmission 
- Attitude about COVID-19 isolation

- Avoiding crowded places to prevent the spread of COVID-19

- Perceptions about COVID-19

- Wearing facemask for COVID-19 protection

- Practicing hand hygiene

No published or in-progress systematic review on this topic was recognized in the Cochrane Library and PROSPERO before this review. The protocol for this systematic review and meta-analysis has been registered in PROSPERO 2020 (CRD42020188371) [29].

\section{Selection of Studies}

Based on the aforementioned inclusion and exclusion criteria, articles using keywords related to the knowledge, attitude, perception, and practice about COVID-19 were selected. The study authors independently screened the titles and abstracts to identify eligible studies. Only full-text papers available in the English language were included. Small changes in the wording were also overlooked to understand their exact functional meaning. The authors excluded duplicates, articles not meeting inclusion/exclusion criteria, and studies in which the data were inadequately reported [Figure 1].

\section{Data Extraction}

The data for this review we extracted the following information such as author names, study design, study location, sampling, methods of administration of the questionnaire, and key results; these data were obtained from the selected articles and recorded in an Excel sheet. The data reported in or calculated from the included studies were used for analysis. Discrepancies related to the inclusion of particular studies were resolved by discussion among authors to reach consensus. 
medRxiv preprint doi: https://doi.org/10.1101/2020.06.24.20138891; this version posted June 24, 2020. The copyright holder for this preprint (which was not certified by peer review) is the author/funder, who has granted medRxiv a license to display the preprint in perpetuity.

It is made available under a CC-BY-NC-ND 4.0 International license .

\section{Quality assessment}

Methodological quality and risk of bias of each included study were evaluated using the Joanna Briggs Institute's checklist for the critical appraisal (i.e., a nine-item checklist to evaluate that the sample is representative of the target population) [30]. Questions included the following: were the study participants recruited appropriately? was the sample size adequate? were the study subjects and settings described precisely? was data analysis used to identify the sample? were objectives and standard criteria used to measure the condition? and were important confounders identified or considered? The methodological quality of the studies was also assessed using the Strengthening the Reporting of Observational Studies in Epidemiology (STROBE) scale [31]. Egger and Begg tests and graphs representing funnel plots evaluated publication bias.

\section{Statistical analysis}

Meta-analysis was performed using STATA version 16 software. The heterogeneity of the studies was evaluated using Cochrane's Q-test and $I^{2}$ statistics. The random-effects model was used to combine the studies showing heterogeneity of Cochrane $\mathrm{Q} p<0.10$ and $I^{2}>50 \%$. A forest plot was used to demonstrate the selected studies in terms of estimates with a $95 \%$ confidence interval (CI). The differences in knowledge, attitude, perception, and practice across various study groups were assessed using subgroup analysis. Sensitivity analysis was also performed by stratified the studies into high quality (over $75 \%$ of the STROBE checklist) and low quality (under $75 \%$ of the STROBE checklist).

\section{Results}

A total of 1441 studies were found in the initial search; 993 were excluded due to unrelated titles. Forty-eight studies were considered for a full-text review, and 29 were excluded based on exclusion criteria. Finally, 19 studies [9-27] were included in the systematic review, and 16 were included in the meta-analysis $[9-14,16,17,19,21-27]$ [Figure 1]. 
medRxiv preprint doi: https://doi.org/10.1101/2020.06.24.20138891; this version posted June 24, 2020. The copyright holder for this preprint (which was not certified by peer review) is the author/funder, who has granted medRxiv a license to display the preprint in perpetuity.

It is made available under a CC-BY-NC-ND 4.0 International license .

\section{Study Characteristics}

Studies considered for the systematic review were cross-sectional studies using online selfadministered or telephone-administered questionnaires. Among the 19 studies included for this review, six were from China $[14,15,18,19,22,23]$, two were from Iran $[11,16]$, two from US [13, 27], one from (US and UK) [20], two from multiple countries [9, 10], with one each of the following from Vietnam [12], India [17], Bangladesh [21], Turkey [24], Jordan [25] and Malaysia [26]. The sample sizes ranged from 85 [11] to 5974 [20]. The primary target population across studies were general population $(n=9)[13,14,17,18,20-23,26]$, healthcare workers [HCWs] $(n=8)[9-12,15,19,24,25]$, medical students $(n=1)[16]$ and people with chronic disease $(n=1)$ [27]. Additional details are reported in Table 1.

\section{Knowledge about COVID-19}

Knowledge about COVID-19 was assessed with two statements and the results are presented in Figures 2 and 3. Nine studies reported the knowledge of COVID-19 symptoms [9, 12-14, 16, 17, 25-27], overall, $79 \%$ (95\% CI: 69-89) of the sample correctly identified COVID-19 related symptoms. Seven studies reported the knowledge of COVID-19 transmission $[9,10$, 12-14, 16, 25] with an overall $82 \%$ (95\% CI: 74-90) are aware of its transmission. Knowledge about COVID-19 transmission was high among the general population (91.8\%) $[13,14]$ while knowledge about COVID-19 symptoms was high among HCWs and medical students $(82.9 \%)[9,12,16,25]$ [Table 2].

\section{Attitude towards COVID-19}

Four studies reported the attitude towards COVID-19 as avoiding crowded areas $[13,14,16$, 23] and $89 \%(95 \%$ CI: $82-95 ; p<0.001)$ of the participants reported that they avoided crowded places to prevent getting COVID-19 [Figure 4]. Subgroup analysis found that medical students [16], as well as the general population [13, 14, 23], had a positive attitude 
medRxiv preprint doi: https://doi.org/10.1101/2020.06.24.20138891; this version posted June 24, 2020. The copyright holder for this preprint (which was not certified by peer review) is the author/funder, who has granted medRxiv a license to display the preprint in perpetuity.

It is made available under a CC-BY-NC-ND 4.0 International license .

towards COVID-19 with $99.6 \%$ and $88 \%$, respectively. More than $95 \%$ of the HCWs $(97.9 \%)$ and general public

(95.9\%) opinioned that COVID-19 patients should be isolated (Table 2).

Perception of COVID-19

Nine studies reported perceptions about COVID-19 [9, 10, 17, 19, 21-23, 25, 26]. Overall, only $46 \%$ (95\% CI: 15-77) of the population studied showed positive perceptions about COVID-19 [Figure 5]. Moreover, these perceptions among HCWs [9, 10, 19, 25] were more positive $(58.9 \%)$ when compared to the general population $(35.1 \%)$ [17, 21-23, 26] [Table 2].

Practice on COVID-19 Prevention

Practice towards COVID-19 prevention was assessed using statements in studies related to wearing a face mask and maintaining hand hygiene. Four studies reported practice related to wearing a face mask to prevent COVID-19 transmission [13, 14, 22, 23] with an overall percentage of $73 \%$ (95\% CI: 61-85) [Figure 6]. For hand hygiene practices, four studies assessed a cumulative sample of 1702 population and $82 \%$ (95\% CI: 68-95) of the sample agreed that they practice hand hygiene to prevent them from COVID-19 [12, 17, 24, 25] [Figure 7]. Subgroup analysis showed that practices among the general population by wearing face mask $[13,14,22,23]$ and hand hygiene [17] were $73.1 \%$ and $97 \%$, respectively. While hand hygiene practice among $\operatorname{HCWs}[12,24,25]$ and medical students [17] was suboptimal $(76.5 \%)$ [Table 2]

Sensitivity analysis

To address the issue of heterogeneity, studies are classified into high (>75\%) and low quality $(<75 \%)$ following the STROBE checklist for methodological quality. No significant differences in the knowledge levels were seen between low- and high-quality studies [Table 3]. Thirteen studies were identified as low-quality at reporting attitude levels $[11,13,14,16$, 
medRxiv preprint doi: https://doi.org/10.1101/2020.06.24.20138891; this version posted June 24, 2020. The copyright holder for this preprint (which was not certified by peer review) is the author/funder, who has granted medRxiv a license to display the preprint in perpetuity.

It is made available under a CC-BY-NC-ND 4.0 International license .

$17,19,21-27]$, with only $46.2 \%$ of the sample had a positive perception about COVID-19.

\section{Study quality assessment}

Study quality was evaluated using the Joanna Briggs Institute's criteria [Table 4]. A set of nine criteria were used to evaluate the quality of studies. Ten studies showed that the sample represented the target population $[9-12,15,16,19,24,25,27]$ and five studies showed that the participants have been recruited appropriately $[9,12,18,22,25]$. Two studies calculated the sample size [16, 24], and 17 studies described their study settings [9-16, 18-20, 22-27]. The majority of the studies conducted the data analysis sufficiently [9-19, 22-27], however, standard criteria were not used to assess the KAP about COVID-19 [9-27]. Some studies measured precisely on HCWs and medical students $[9,10,16,19]$, used appropriate statistical analysis $[9,12-16,18,19,22-24,26]$, but none identified major confounders and subgroups [9-27].

\section{Publication Bias}

Publication bias was highlighted in all the 16 studies and was confirmed by asymmetric funnel plots (Supplementary file). Further investigating the extent of publication bias across the statements, the Egger test identified a considerable proportion of bias identified in the knowledge statements related to COVID-19 transmission and COVID-19 symptoms $(p<0.05)$. However, the Begg test did not identify any publication bias across the statements $(p>0.05)$ [Table 5].

\section{Discussion}

In this first and largest review, we assess the nature and extent of KAP towards COVID-19 during the pandemic period from January to May 31, 2020. Two recent reviews focused on 
medRxiv preprint doi: https://doi.org/10.1101/2020.06.24.20138891; this version posted June 24, 2020. The copyright holder for this preprint (which was not certified by peer review) is the author/funder, who has granted medRxiv a license to display the preprint in perpetuity.

It is made available under a CC-BY-NC-ND 4.0 International license .

understanding the extent of preparedness of medical students towards disaster training programs [32] and efficacy of face mask in preventing respiratory virus [33]. Absent a vaccine or drug therapy to prevent and cure COVID-19 infection, there is irrefutable evidence on prevention of transmission by public health measures such as handwashing, wearing masks, and practicing social distancing. In this review of 19 studies [9-27], results provide robust evidence about KAP gaps in COVID-19 infection. For example, we found that the majority of the sample had good knowledge of COVID-19 clinical symptoms (79\%) and its transmission (82\%), and the majority (89\%) agreed that individuals should avoid going to crowded places to prevent COVID-19 transmission. Furthermore, more than $50 \%$ of the cumulative sample had negative perceptions about COVID-19. Overall, nearly three-fourth (73\%) of the sample indicated that COVID-19 prevention practices such as wearing face masks and maintaining hand hygiene should be prioritized to prevent its transmission.

People's knowledge, attitude, perceptions, and practices about COVID-19 are important predictors of whether they engage in disease-specific preventive behaviors. Evidence from prior studies indicates that higher knowledge about infectious diseases is positively associated with increased engagement in appropriate protective behavior during an outbreak [34-37]. However, widespread endorsement of medical conspiracy beliefs to counter scientific evidence can inhibit preventive behavior [38-40]. In several instances, knowledge can also influence perceptions due to past experiences and beliefs [40-42]. The findings of this study suggest a significant gap between the amount of knowledge, attitude, and prevention practices related to COVID-19 infection. This is a critical finding as the perceptions of COVID-19 could be important predictors of whether people engage in diseasespecific preventive behaviors or not. Furthermore, the knowledge and perceptions share some of the same psychological motivations such as perceived risk and self-efficacy to control COVID-19. Although we did not investigate the underlying reasons for variations in risk 
medRxiv preprint doi: https://doi.org/10.1101/2020.06.24.20138891; this version posted June 24, 2020. The copyright holder for this preprint (which was not certified by peer review) is the author/funder, who has granted medRxiv a license to display the preprint in perpetuity.

It is made available under a CC-BY-NC-ND 4.0 International license .

perceptions, additional research is warranted based on psychological theories and health behavior change models to explore and explain the connections between KAP and COVID19 preventive behaviors such as mask-wearing.

The findings of this review specifically point to a widespread lack of practice of maskwearing to prevent COVID-19 among study subjects. Wearing a face mask as appropriate is important to prevent transmission of COVID-19 infections and can act as a physical barrier to the spread of droplets. While mask-wearing was not recommended initially by health agencies such as the World health organization [43] and US Center for Disease Control [44] as a key strategy to reduce transmission of COVID-19 in the community, continuing accumulation of evidence now suggests that mask-wearing is one of the key preventive behaviors to halt the community-based spread of the infection [45-47].

A major disconcerting finding of this review pertains to HCWs and medical students. One would assume that these groups of individuals would have a better outlook and behaviors regarding COVID-19 given their field of training and expertise. However, our subgroup analysis found that the level of knowledge on the disease (56.5\%) and perceptions (58.9\%) about COVID-19 among HCWs and medical students are suboptimal. Such a deficit during an ongoing pandemic may result in delayed recognition and handling of potential COVID-19 patients. Furthermore, if these perceptions are truly representative, this could have an impact on patient care and also on the dynamics of the COVID-19 outbreak. There is an urgent need to develop evidence-based educational interventions to improve HCWs level of knowledge and to alter their KAP.

\section{Limitations}

The results of this review must be considered in light of several potential limitations. The meta-analysis shows high heterogeneity with a lack of homogeneity of the responses of participants among various studies. This could be due to sociodemographic and socio-cultural 
medRxiv preprint doi: https://doi.org/10.1101/2020.06.24.20138891; this version posted June 24, 2020. The copyright holder for this preprint (which was not certified by peer review) is the author/funder, who has granted medRxiv a license to display the preprint in perpetuity.

It is made available under a CC-BY-NC-ND 4.0 International license .

variations among different study subjects and differences in questionnaire content and administration. These issues may have led to selection bias. Moreover, we used a set of questions to quantify the level of KAP about COVID-19 and published until the end of May 2020 are included. Thus, our analysis may have missed additional findings from the literature. Furthermore, our analysis used secondary data in the published literature that some of the responses may overestimate or underestimate while providing results that might lead to reporting or recall bias. The Quality assessment of each included study allowed us to evaluate the presence of potential bias and confounding. Also, funnel plots revealed asymmetry across all outcomes. Thus, caution should be taken while interpreting the results of this review. Despite this, no publication bias was identified by the Begg test. Lastly, this review has the largest sample size, with the latest findings, and covers the widest geography to date on the topics under investigation.

\section{Conclusion}

Our results identified a high majority of the sample exhibited negative perceptions about COVID-19 and preventive practice of wearing face masks and maintaining hand hygiene are suboptimal. Most of the HCWs and medical students have poor knowledge and two-third $(65 \%)$ of the general public have a negative attitude towards COVID-19. Reinforcing evidence-based educational interventions among HCWs and reinforcing prevention guidelines to improve their understanding and thus can alter the KAP in the general population during the COVID-19 era.

Acknowledgment: We thank PROSPERO for reviewing the protocol and providing their support in fulfilling the research work.

Authors' contributions: All the authors equally contributed in literature review, data collection, analysis, and writing the manuscript. All authors have read and approved the final manuscript. 
medRxiv preprint doi: https://doi.org/10.1101/2020.06.24.20138891; this version posted June 24, 2020. The copyright holder for this preprint (which was not certified by peer review) is the author/funder, who has granted medRxiv a license to display the preprint in perpetuity.

It is made available under a CC-BY-NC-ND 4.0 International license .

Funding: No source of funding

Available data and materials: All materials are attached as supplementary materials, and information related to the study is in the manuscript.

Competing interests: The authors declare that they have no competing interests.

\section{References.}

1. WHO Coronavirus disease 2019 (COVID-19) situation report - 145. June 13, 2020.

https://www.who.int/docs/default-source/coronaviruse/situation-reports/20200613-covid-19sitrep-145.pdf?sfvrsn=bb7c1dc9 2.

2. World Health Organization. World Health Organization. 2020. Coronavirus disease (COVID-19) training: Online training. https://www.who.int/emergencies/diseases/novelcoronavirus-2019/training/online-training.

3. Centers for Disease Control and Prevention. 2019. Coronavirus (COVID-19) https://www.cdc.gov/coronavirus/2019-ncov/index.html.

4. United Nations COVID-19 response. Coronavirus global health emergency. https://www.un.org/en/coronavirus.

5. Sohrabi C, Alsafi Z, O’Neill N, Khan M, Kerwan A, Al-Jabir A, Iosifidis C, Agha R. World Health Organization declares global emergency: A review of the 2019 novel coronavirus (COVID-19). Int J Surg. 2020;76:71-76.

6. Greenhalgh T, Schmid MB, Czypionka T, Bassler D, Gruer L. Face masks for the public during the covid-19 crisis. BMJ. 2020;369: m1435.

7. McKee M, Gill M, Wollaston S. Public inquiry into UK's response to covid-19. BMJ 2020;369:m2052

8. James JJ. COVID-19: from epidemic to pandemic. Disaster Med Public Health Prepare 2020. Doi: 10.1017/dmp.2020.84.

9. Bhagavathula AS, Aldhaleei WA, Rahmani J, Mahabadi MA, Bandari DK. Knowledge and Perceptions of COVID-19 Among Health Care Workers: Cross-Sectional Study. JMIR Public Health Surveill. 2020;6(2):e19160.

10. Ahmed MA, Jouhar R, Ahmed N, Adnan S, Aftab M, Zafar MS, Khurshid Z. Fear and practice modifications among dentists to combat novel coronavirus disease (COVID-19) outbreak. Int J Environment Res Public Health. 2020;17(8):2821. 
medRxiv preprint doi: https://doi.org/10.1101/2020.06.24.20138891; this version posted June 24, 2020. The copyright holder for this preprint (which was not certified by peer review) is the author/funder, who has granted medRxiv a license to display the preprint in perpetuity.

It is made available under a CC-BY-NC-ND 4.0 International license .

11. Nemati M, Ebrahimi B, Nemati F. Assessment of Iranian nurses' knowledge and anxiety toward COVID-19 during the current outbreak in Iran. Arch. Clin. Infect. Dis. 2020;15:e102848.

12. Giao H, Han NT, Van Khanh T, Ngan VK, Van Tam V, Le An P. Knowledge and attitude toward COVID-19 among healthcare workers at District 2 Hospital, Ho Chi Minh City. Asia Pacific J Trop Med. 2020;13:3-5.

13. Clements JM. Knowledge and behaviors toward COVID-19 among US residents during the early days of the pandemic. JMIR Public Health Surveill 2020;6(2):e19161.

14. Zhong BL, Luo W, Li HM, Zhang QQ, Liu XG, Li WT, Li Y. Knowledge, attitudes, and practices towards COVID-19 among Chinese residents during the rapid rise period of the COVID-19 outbreak: a quick online cross-sectional survey. Int J Biol Sci. 2020;16(10):1745.

15. Shi Y, Wang J, Yang Y, Wang Z, Wang G, Hashimoto K, Zhang K, Liu H. Knowledge and attitudes of medical staff in Chinese psychiatric hospitals regarding COVID-19. Brain Behav Immun. 2020;4:100064.

16. Taghrir MH, Borazjani R, Shiraly R. COVID-19 and Iranian Medical Students; A Survey on Their Related-Knowledge, Preventive Behaviors and Risk Perception. Arch Iran Med. 2020;23(4):249-54.

17. Roy D, Tripathy S, Kar SK, Sharma N, Verma SK, Kaushal V. Study of knowledge, attitude, anxiety \& perceived mental healthcare need in Indian population during COVID-19 pandemic. Asian J Psych. 2020;51:102083.

18. Li JB, Yang A, Dou K, Wang LX, Zhang MC, Lin X. Chinese public's knowledge, perceived severity, and perceived controllability of the COVID-19 and their associations with emotional and behavioural reactions, social participation, and precautionary behaviour: A national survey. PsyArXiv Preprints 2020. Doi: 10.31234/osf.io/5tmsh.

19. Kang L, Ma S, Chen M, Yang J, Wang Y, Li R, Yao L, Bai H, Cai Z, Yang BX, Hu S. Impact on mental health and perceptions of psychological care among medical and nursing staff in Wuhan during the 2019 novel coronavirus disease outbreak: A cross-sectional study. Brain Behav Immun. 2020. Doi: 10.1016/j.bbi.2020.03.028.

20. Geldsetzer P. Use of rapid online surveys to assess People's perceptions during infectious disease outbreaks: a cross-sectional survey on COVID-19. Journal of medical Internet research. 2020;22(4):e18790.

21. Islam MD, Siddika A. COVID-19 and Bangladesh: A study of the public perception on the measures taken by the government. EdArXiv 202. Doi: 10.13140/RG.2.2.30042.49608. 
medRxiv preprint doi: https://doi.org/10.1101/2020.06.24.20138891; this version posted June 24, 2020. The copyright holder for this preprint (which was not certified by peer review) is the author/funder, who has granted medRxiv a license to display the preprint in perpetuity.

It is made available under a CC-BY-NC-ND 4.0 International license .

22. Qian M, Wu Q, Wu P, Hou Z, Liang Y, Cowling BJ, Yu H. Psychological responses, behavioral changes and public perceptions during the early phase of the COVID-19 outbreak in China: a population based cross-sectional survey. MedRxiv. 2020. Doi: 10.1101/2020.02.18.20024448.

23. Kwok KO, Li KK, Chan HH, Yi YY, Tang A, Wei WI, Wong YS. Community responses during the early phase of the COVID-19 epidemic in Hong Kong: risk perception, information exposure and preventive measures. MedRxiv 2020. Doi: 10.1101/2020.02.26.20028217.

24. Dost B, Koksal E, Terzi Ö, Bilgin S, Ustun YB, Arslan HN. Attitudes of Anesthesiology Specialists and Residents Toward Patients Infected with the Novel Coronavirus (COVID-19): A National Survey Study. Surg Infect. 2020;21(4):350-6.

25. Khader Y, Al Nsour M, Al-Batayneh OB, Saadeh R, Bashier H, Alfaqih M, Al-Azzam S. Dentists' Awareness, Perception, and Attitude Regarding COVID-19 and Infection Control: Cross-Sectional Study Among Jordanian Dentists. JMIR Public Health Surveill. 2020;6(2):e18798.

26. Khayriuuah $\mathrm{MH}$, Da CW. Public knowledge, perception and communication behavior surrounding COVID-19 in Malaysia. SageSubmissions. Preprint 2020. Doi: 10.31124/advance.12102816.v1

27. Wolf MS, Serper M, Opsasnick L, O'Conor RM, Curtis LM, Benavente JY, Wismer G, Batio S, Eifler M, Zheng P, Russell A. Awareness, attitudes, and actions related to COVID19 among adults with chronic conditions at the onset of the US outbreak: a cross-sectional survey. Ann Inter Med 2020. Doi:10.7326/M20-1239.

28.

PROSPERO.

https://www.crd.york.ac.uk/prospero/display record.php?RecordID=188371

29. Moher D, Liberati A, Tetzlaff J, Altman DG, Prisma Group. Preferred reporting items for systematic reviews and meta-analyses: the PRISMA statement. PLoS Med. 2009;6(7):e1000097.

30. Munn Z, Moola S, Riitano D, Lisy K. The development of a critical appraisal tool for use in systematic reviews addressing questions of prevalence. Int $\mathbf{J}$ Health Policy Manag 2014;3(3):123-8.

31. Von Elm E, Altman DG, Egger M, Pocock SJ, Gøtzsche PC, Vandenbroucke JP. The Strengthening the Reporting of Observational Studies in Epidemiology (STROBE) statement: guidelines for reporting observational studies. J Clin Epidemiol 2008;61(4):344-349. 
medRxiv preprint doi: https://doi.org/10.1101/2020.06.24.20138891; this version posted June 24, 2020. The copyright holder for this preprint (which was not certified by peer review) is the author/funder, who has granted medRxiv a license to display the preprint in perpetuity. It is made available under a CC-BY-NC-ND 4.0 International license .

32. Ashcroft J, Byrne MHV, Brennan PA, Davies RJ. Preparing medical students for a pandemic: a systematic review of student disaster training programmes. Postgrad Med J. 2020. Doi: 10.1136/postgradmedj-2020-137906.

33. Liang M, Gao L, Cheng C, Zhou Q, Uy JP, Heiner K, Sun C. Efficacy of face mask in preventing respiratory virus transmission: A systematic review and meta-analysis. Travel Med Infect Dis. 2020:101751. doi: 10.1016/j.tmaid.2020.101751.

34. Prue CE, Roth Jr JN, Garcia-Williams A, Yoos A, Camperlengo L, DeWilde L, Lamtahri M, Prosper A, Harrison C, Witbart L, Guendel I. Awareness, beliefs, and actions concerning Zika virus among pregnant women and community members-US Virgin Islands, November-December 2016. MMWR. Morbid Mortal Weekly Rep 2017;66(34):909.

35. Lunn PD, Belton CA, Lavin C, McGowan FP, Timmons S, Robertson DA. Using Behavioral Science to help fight the Coronavirus. J Behav Public Admin. 2020;3(1):1-15.

36. Toppenberg-Pejcic D, Noyes J, Allen T, Alexander N, Vanderford M, Gamhewage G. Emergency Risk Communication: Lessons Learned from a Rapid Review of Recent Gray Literature on Ebola, Zika, and Yellow Fever. Health Commun. 2019 Apr;34(4):437-455

37. Gentili D, Bardin A, Ros E, Piovesan C, Ramigni M, Dalmanzio M, Dettori M, Filia A, Cinquetti S. Impact of Communication Measures Implemented During a School Tuberculosis Outbreak on Risk Perception among Parents and School Staff, Italy, 2019. Int J Environ Res Public Health. 2020;17(3):911.

38. Chowell G, Nishiura H. Transmission dynamics and control of Ebola virus disease (EVD): a review. BMC Med. 2014;12(1):196.

39. Piltch $\square$ Loeb R, Zikmund $\square$ Fisher BJ, Shaffer VA, Scherer LD, Knaus M, Fagerlin A, Abramson DM, Scherer AM. Cross $\square$ Sectional Psychological and Demographic Associations of Zika Knowledge and Conspiracy Beliefs Before and After Local Zika Transmission. Risk Analysis. 201;39(12):2683-93.

40. Hogg R, Nkala B, Dietrich J, Collins A, Closson K, Cui Z, Kanters S, Chia J, Barhafuma B, Palmer A, Kaida A. Conspiracy beliefs and knowledge about HIV origins among adolescents in Soweto, South Africa. PLoS ONE. 2017;12(2):e0165087.

41. Oppenheim B, Lidow N, Ayscue P, Saylors K, Mbala P, Kumakamba C, Kleinman M. Knowledge and beliefs about Ebola virus in a conflict-affected area: early evidence from the North Kivu outbreak. J Glob Health. 2019;9(2):020311.

42. Vinck P, Pham PN, Bindu KK, Bedford J, Nilles EJ. Institutional trust and misinformation in the response to the 2018-19 Ebola outbreak in North Kivu, DR Congo: a population-based survey. Lancet Infect Dis. 2019;19(5):529-36. 
medRxiv preprint doi: https://doi.org/10.1101/2020.06.24.20138891; this version posted June 24, 2020. The copyright holder for this preprint (which was not certified by peer review) is the author/funder, who has granted medRxiv a license to display the preprint in perpetuity.

It is made available under a CC-BY-NC-ND 4.0 International license.

43. WHO. Coronavirus disease (COVID-19) advice for the public: when and how to use masks. Available at: https://www.who.int/emergencies/diseases/novel-coronavirus2019/advice-for-public/when-and-how-to-use-masks.html

44. CDC. Coronavirus Disease 2019 (COVID-19): steps to prevent illness. Available at: https://www.cdc.gov/coronavirus/2019-ncov/about/prevention-treatment.html

45. Feng S, Shen C, Xia N, Song W, Fan M, Cowling BJ. Rational use of face masks in the COVID-19 pandemic. Lancet Respir Med. 2020;8(5):434-436.

46. West R, Michie S, Rubin GJ, Amlôt R. Applying principles of behaviour change to reduce SARS-CoV-2 transmission. Nat Hum Behav. 2020;4:451-459.

47. Leung NHL, Chu DKW, Shiu EYC, Chan KH, McDevitt JJ, Hau BJP, Yen HL, Li Y, Ip

DKM, Peiris JSM, Seto WH, Leung GM, Milton DK, Cowling BJ. Respiratory virus shedding in exhaled breath and efficacy of face masks. Nat Med. 2020;26(5):676-680. 
Table 1. Characteristics of the cross-sectional studies included in Systematic review and Meta-analysis $(\mathrm{N}=27,617)$

\begin{tabular}{|c|c|c|c|c|c|c|c|c|c|}
\hline References & Author & Year & Journal & Study location & $\begin{array}{c}\text { Quality } \\
\text { assessment }\end{array}$ & $\begin{array}{c}\text { Sample } \\
\text { size }\end{array}$ & Focusing group & $\begin{array}{c}\text { Questionnaire } \\
\text { administration }\end{array}$ & Outcome \\
\hline \multicolumn{10}{|c|}{ Studies included for the systematic review } \\
\hline 9 & Bhagavathula et al & 2020 & $\begin{array}{l}\text { JMIR Public Health } \\
\text { and Surveillance }\end{array}$ & Multiple & $>75 \%$ & 453 & $\begin{array}{l}\text { Healthcare } \\
\text { workers }\end{array}$ & $\begin{array}{l}\text { Online self- } \\
\text { administered }\end{array}$ & $\begin{array}{c}\text { poor knowledge, } \\
\text { positive } \\
\text { perception }\end{array}$ \\
\hline 10 & Ahmed et al & 2020 & $\begin{array}{c}\text { International Journal } \\
\text { of Environmental } \\
\text { Research and Public } \\
\text { Health } \\
\end{array}$ & 30 countries & $>75 \%$ & 650 & Dentists & $\begin{array}{l}\text { Online self- } \\
\text { administered }\end{array}$ & $\begin{array}{l}\text { positive } \\
\text { knowledge, } \\
\text { negative } \\
\text { perception }\end{array}$ \\
\hline 11 & Nemati et al & 2020 & $\begin{array}{l}\text { Arch. Clin. Infect. } \\
\text { Dis. }\end{array}$ & Iran & $<75 \%$ & 85 & Nurses & $\begin{array}{l}\text { Online self- } \\
\text { administered }\end{array}$ & $\begin{array}{c}\text { positive } \\
\text { knowledge }\end{array}$ \\
\hline 12 & Giao et al & 2020 & Asian Pac J Trop Med & Vietnam & $>75 \%$ & 327 & $\begin{array}{l}\text { Healthcare } \\
\text { workers }\end{array}$ & $\begin{array}{l}\text { Online self- } \\
\text { administered }\end{array}$ & $\begin{array}{c}\text { positive } \\
\text { knowledge and } \\
\text { attitude }\end{array}$ \\
\hline 13 & Clements & 2020 & MedRxiv & US & $<75 \%$ & 1070 & $\begin{array}{c}\text { General } \\
\text { population }\end{array}$ & $\begin{array}{l}\text { Online self- } \\
\text { administered }\end{array}$ & $\begin{array}{c}\text { positive } \\
\text { knowledge }\end{array}$ \\
\hline 14 & Zhong et al & 2020 & $\begin{array}{l}\text { International journal } \\
\text { of biological sciences }\end{array}$ & China & $<75 \%$ & 6910 & $\begin{array}{l}\text { General } \\
\text { population }\end{array}$ & $\begin{array}{l}\text { Online self- } \\
\text { administered }\end{array}$ & $\begin{array}{l}\text { positive } \\
\text { knowledge, } \\
\text { attitude and } \\
\text { practice }\end{array}$ \\
\hline 15 & Shi et al & 2020 & $\begin{array}{l}\text { Brain, Behavior, \& } \\
\text { Immunity-Health }\end{array}$ & China & $<75 \%$ & 311 & $\begin{array}{l}\text { Healthcare } \\
\text { workers }\end{array}$ & $\begin{array}{l}\text { Online self- } \\
\text { administered }\end{array}$ & $\begin{array}{c}\text { positive } \\
\text { knowledge and } \\
\text { attitude }\end{array}$ \\
\hline 16 & Taghrir et al & 2020 & $\begin{array}{c}\text { Archives of Iranian } \\
\text { Medicine }\end{array}$ & Iran & $<75 \%$ & 240 & Medical students & $\begin{array}{l}\text { Online self- } \\
\text { administered }\end{array}$ & $\begin{array}{c}\text { positive } \\
\text { knowledge and } \\
\text { practice }\end{array}$ \\
\hline 17 & Roy et al & 2020 & $\begin{array}{l}\text { Asian Journal of } \\
\text { Psychiatry }\end{array}$ & India & $<75 \%$ & 662 & $\begin{array}{l}\text { General } \\
\text { population }\end{array}$ & $\begin{array}{l}\text { Online self- } \\
\text { administered }\end{array}$ & $\begin{array}{c}\text { modest } \\
\text { knowledge and } \\
\text { attitude, negative } \\
\text { perception }\end{array}$ \\
\hline 18 & $\mathrm{Li}$ et al & 2020 & PsyArXiv & China & $<75 \%$ & 4607 & $\begin{array}{c}\text { General } \\
\text { population }\end{array}$ & $\begin{array}{l}\text { Online self- } \\
\text { administered }\end{array}$ & $\begin{array}{c}\text { positive } \\
\text { knowledge and } \\
\text { perception }\end{array}$ \\
\hline 19 & Kang et al & 2020 & $\begin{array}{l}\text { Brain, behavior, and } \\
\text { immunity }\end{array}$ & China & $<75 \%$ & 994 & $\begin{array}{c}\text { Healthcare } \\
\text { workers }\end{array}$ & $\begin{array}{l}\text { Online self- } \\
\text { administered }\end{array}$ & $\begin{array}{l}\text { negative } \\
\text { perception }\end{array}$ \\
\hline 20 & Geldsetzer et al. & 2020 & $\begin{array}{l}\text { Journal of medical } \\
\text { Internet research }\end{array}$ & US and UK & $>75 \%$ & 5974 & $\begin{array}{c}\text { General } \\
\text { population }\end{array}$ & $\begin{array}{l}\text { Online self- } \\
\text { administered }\end{array}$ & $\begin{array}{l}\text { negative } \\
\text { perception }\end{array}$ \\
\hline 21 & Islam et al & 2020 & PsyArXiv & Bangladesh & $<75 \%$ & 190 & $\begin{array}{c}\text { General } \\
\text { population }\end{array}$ & $\begin{array}{l}\text { Online self- } \\
\text { administered }\end{array}$ & $\begin{array}{c}\text { positive } \\
\text { knowledge and }\end{array}$ \\
\hline
\end{tabular}




\begin{tabular}{|c|c|c|c|c|c|c|c|c|c|}
\hline & & & & & & & & & $\begin{array}{l}\text { negative } \\
\text { perception }\end{array}$ \\
\hline 22 & Qian et al & 2020 & MedRxiv & China & $<75 \%$ & 1011 & $\begin{array}{c}\text { General } \\
\text { population }\end{array}$ & $\begin{array}{l}\text { Telephone- } \\
\text { administered }\end{array}$ & $\begin{array}{l}\text { positive practice } \\
\text { and perception }\end{array}$ \\
\hline 23 & Kwok et al & 2020 & MedRxiv & China & $<75 \%$ & 1715 & $\begin{array}{c}\text { General } \\
\text { population }\end{array}$ & $\begin{array}{l}\text { Online self- } \\
\text { administered }\end{array}$ & $\begin{array}{l}\text { positive practice } \\
\text { and negative } \\
\text { perception }\end{array}$ \\
\hline 24 & Dost et al & 2020 & Surgical Infections & Turkey & $<75 \%$ & 346 & $\begin{array}{c}\text { Healthcare } \\
\text { workers }\end{array}$ & $\begin{array}{l}\text { Online self- } \\
\text { administered }\end{array}$ & positive attitude \\
\hline 25 & Khader et al & 2020 & $\begin{array}{l}\text { JMIR Public Health } \\
\text { and Surveillance }\end{array}$ & Jordan & $<75 \%$ & 367 & Dentist & $\begin{array}{l}\text { Online self- } \\
\text { administered }\end{array}$ & $\begin{array}{c}\text { positive } \\
\text { knowledge, } \\
\text { attitude and } \\
\text { perception } \\
\end{array}$ \\
\hline 26 & Mohd Hanafiah et al & 2020 & sage preprint & Malaysia & $<75 \%$ & 1075 & $\begin{array}{l}\text { General } \\
\text { population }\end{array}$ & $\begin{array}{l}\text { Online self- } \\
\text { administered }\end{array}$ & $\begin{array}{c}\text { positive } \\
\text { knowledge and } \\
\text { negative } \\
\text { perception }\end{array}$ \\
\hline 27 & Wolf et al & 2020 & $\begin{array}{l}\text { Annals of Internal } \\
\text { Medicine }\end{array}$ & US & $<75 \%$ & 630 & Chronic disease & $\begin{array}{l}\text { Telephone- } \\
\text { administered }\end{array}$ & $\begin{array}{c}\text { positive } \\
\text { knowledge }\end{array}$ \\
\hline \multicolumn{10}{|c|}{ Studies included in the systematic review and Meta-analysis } \\
\hline 9 & Bhagavathula et al & 2020 & $\begin{array}{l}\text { JMIR Public Health } \\
\text { and Surveillance }\end{array}$ & Multiple & $>75 \%$ & 453 & $\begin{array}{l}\text { Healthcare } \\
\text { workers }\end{array}$ & $\begin{array}{l}\text { Online self- } \\
\text { administered }\end{array}$ & $\begin{array}{l}\text { poor knowledge, } \\
\text { positive } \\
\text { perception }\end{array}$ \\
\hline 10 & Ahmed et al & 2020 & $\begin{array}{c}\text { International Journal } \\
\text { of Environmental } \\
\text { Research and Public } \\
\text { Health }\end{array}$ & 30 countries & $>75 \%$ & 650 & Dentists & $\begin{array}{l}\text { Online self- } \\
\text { administered }\end{array}$ & $\begin{array}{c}\text { positive } \\
\text { knowledge, } \\
\text { negative } \\
\text { perception }\end{array}$ \\
\hline 11 & Nemati et al & 2020 & $\begin{array}{l}\text { Arch. Clin. Infect. } \\
\text { Dis. }\end{array}$ & Iran & $<75 \%$ & 85 & Nurses & $\begin{array}{c}\text { Online self- } \\
\text { administered }\end{array}$ & $\begin{array}{c}\text { positive } \\
\text { knowledge }\end{array}$ \\
\hline 12 & Giao et al & 2020 & Asian Pac J Trop Med & Vietnam & $>75 \%$ & 327 & $\begin{array}{l}\text { Healthcare } \\
\text { workers }\end{array}$ & $\begin{array}{l}\text { Online self- } \\
\text { administered }\end{array}$ & $\begin{array}{c}\text { positive } \\
\text { knowledge and } \\
\text { attitude }\end{array}$ \\
\hline 13 & Clements & 2020 & MedRxiv & US & $<75 \%$ & 1070 & $\begin{array}{c}\text { General } \\
\text { population }\end{array}$ & $\begin{array}{c}\text { Online self- } \\
\text { administered }\end{array}$ & $\begin{array}{c}\text { positive } \\
\text { knowledge }\end{array}$ \\
\hline 14 & Zhong et al & 2020 & $\begin{array}{l}\text { International journal } \\
\text { of biological sciences }\end{array}$ & China & $<75 \%$ & 6910 & $\begin{array}{l}\text { General } \\
\text { population }\end{array}$ & $\begin{array}{l}\text { Online self- } \\
\text { administered }\end{array}$ & $\begin{array}{c}\text { positive } \\
\text { knowledge, } \\
\text { attitude and } \\
\text { practice }\end{array}$ \\
\hline 16 & Taghrir et al & 2020 & $\begin{array}{l}\text { Archives of Iranian } \\
\text { Medicine }\end{array}$ & Iran & $<75 \%$ & 240 & Medical students & $\begin{array}{l}\text { Online self- } \\
\text { administered }\end{array}$ & $\begin{array}{c}\text { positive } \\
\text { knowledge and } \\
\text { practice }\end{array}$ \\
\hline 17 & Roy et al & 2020 & Asian Journal of & India & $<75 \%$ & 662 & General & Online self- & modest \\
\hline
\end{tabular}




\begin{tabular}{|c|c|c|c|c|c|c|c|c|c|}
\hline & & & Psychiatry & & & & population & administered & $\begin{array}{l}\text { knowledge and } \\
\text { attitude, negative } \\
\text { perception }\end{array}$ \\
\hline 19 & Kang et al & 2020 & $\begin{array}{c}\text { Brain, behavior, and } \\
\text { immunity }\end{array}$ & China & $<75 \%$ & 994 & $\begin{array}{c}\text { Healthcare } \\
\text { workers }\end{array}$ & $\begin{array}{l}\text { Online self- } \\
\text { administered }\end{array}$ & $\begin{array}{l}\text { negative } \\
\text { perception }\end{array}$ \\
\hline 21 & Islam et al & 2020 & PsyArXiv & Bangladesh & $<75 \%$ & 190 & $\begin{array}{l}\text { General } \\
\text { population }\end{array}$ & $\begin{array}{l}\text { Online self- } \\
\text { administered }\end{array}$ & $\begin{array}{c}\text { positive } \\
\text { knowledge and } \\
\text { negative } \\
\text { perception } \\
\end{array}$ \\
\hline 22 & Qian et al & 2020 & MedRxiv & China & $<75 \%$ & 1011 & $\begin{array}{c}\text { General } \\
\text { population }\end{array}$ & $\begin{array}{l}\text { Telephone- } \\
\text { administered }\end{array}$ & $\begin{array}{c}\text { positive practice } \\
\text { and perception }\end{array}$ \\
\hline 23 & Kwok et al & 2020 & MedRxiv & China & $<75 \%$ & 1715 & $\begin{array}{c}\text { General } \\
\text { population }\end{array}$ & $\begin{array}{l}\text { Online self- } \\
\text { administered }\end{array}$ & $\begin{array}{l}\text { positive practice } \\
\text { and negative } \\
\text { perception }\end{array}$ \\
\hline 24 & Dost et al & 2020 & Surgical Infections & Turkey & $<75 \%$ & 346 & $\begin{array}{l}\text { Healthcare } \\
\text { workers }\end{array}$ & $\begin{array}{l}\text { Online self- } \\
\text { administered }\end{array}$ & positive attitude \\
\hline 25 & Khader et al & 2020 & $\begin{array}{l}\text { JMIR Public Health } \\
\text { and Surveillance }\end{array}$ & Jordan & $<75 \%$ & 367 & Dentist & $\begin{array}{l}\text { Online self- } \\
\text { administered }\end{array}$ & $\begin{array}{c}\text { positive } \\
\text { knowledge, } \\
\text { attitude and } \\
\text { perception }\end{array}$ \\
\hline 26 & Mohd Hanafiah et al & 2020 & sage preprint & Malaysia & $<75 \%$ & 1075 & $\begin{array}{c}\text { General } \\
\text { population }\end{array}$ & $\begin{array}{l}\text { Online self- } \\
\text { administered }\end{array}$ & $\begin{array}{c}\text { positive } \\
\text { knowledge and } \\
\text { negative } \\
\text { perception } \\
\end{array}$ \\
\hline 27 & Wolf et al. & 2020 & $\begin{array}{c}\text { Annals of Internal } \\
\text { Medicine }\end{array}$ & US & $<75 \%$ & 630 & Chronic disease & $\begin{array}{l}\text { Telephone- } \\
\text { administered }\end{array}$ & $\begin{array}{c}\text { positive } \\
\text { knowledge }\end{array}$ \\
\hline
\end{tabular}


Table 2: Knowledge, attitude, Perception and Practice about COVID-19 among various study groups

\begin{tabular}{|l|l|l|l|l|l|l|}
\hline & $\begin{array}{l}\text { No of } \\
\text { studies }\end{array}$ & $\begin{array}{l}\text { Sample } \\
\text { Size }\end{array}$ & Estimates & $\mathbf{9 5 \%}$ CI & P-value & $\boldsymbol{I}^{\mathbf{2}}$ \\
\hline HCWs and medical students & & & & & \\
\hline General knowledge & 1 & 85 & 56.5 & $45.9-67$ & - & - \\
\hline Knowledge about transmission & 5 & 2037 & 77.3 & $59.9-94.7$ & $<0.001$ & $99.4 \%$ \\
\hline Symptoms & 4 & 1387 & 82.9 & $71.3-94.5$ & $<0.001$ & $97.6 \%$ \\
\hline Attitude about COVID-19 isolation & 1 & 327 & 97.9 & $96.3-99.4$ & - & - \\
\hline Avoiding crowded areas & 1 & 240 & 99.6 & $98.8-100.4$ & - & - \\
\hline Perception about COVID-19 & 4 & 2464 & 58.9 & $13.2-104.7$ & $<0.001$ & $99.9 \%$ \\
\hline Hand hygiene can prevent COVID-19 & 3 & 1040 & 76.5 & $58-95$ & $<0.001$ & $98.5 \%$ \\
\hline Practice about COVID-19, wearing mask & - & - & - & - & - & - \\
\hline General population & & & & & & \\
\hline General knowledge & 1 & 190 & 73.2 & $66.9-79.5$ & - & - \\
\hline Knowledge about transmission & 2 & 7980 & 91.8 & $79.9-103.6$ & $<0.001$ & $99.2 \%$ \\
\hline Symptoms & 4 & 9717 & 76.7 & $60.9-93.3$ & $<0.001$ & $99.8 \%$ \\
\hline Attitude about COVID-19 isolation & 1 & 662 & 95.9 & $94.4-97.4$ & - & - \\
\hline Avoiding crowded areas & 3 & 9695 & 88 & $86.5-89.6$ & $<0.001$ & $99.5 \%$ \\
\hline Perception about COVID-19 & 5 & 4653 & 35.1 & $5.5-64.7$ & $<0.001$ & $99.8 \%$ \\
\hline Hand hygiene can prevent COVID-19 & 1 & 662 & 97 & $95.7-98.3$ & - & - \\
\hline Practice about COVID-19, wearing mask & 4 & 10706 & 73.1 & $60.8-85.3$ & $<0.001$ & $99.9 \%$ \\
\hline Patients with Chronic diseases & & & & & & - \\
\hline Symptoms & 1 & 630 & 71.6 & $68.1-75.1$ & - & - \\
\hline
\end{tabular}


Table 3: Subgroup analysis: Quality of studies

\begin{tabular}{|l|c|c|c|c|c|c|}
\hline $\begin{array}{l}\text { High Quality studies (>75\% } \\
\text { response rate) }\end{array}$ & $\begin{array}{c}\text { No of } \\
\text { studies }\end{array}$ & $\begin{array}{c}\text { Sample } \\
\text { size }\end{array}$ & $\begin{array}{c}\text { Estimates } \\
\mathbf{( \% )}\end{array}$ & $\mathbf{9 5 \%}$ CI & P-value & $\mathbf{I}^{\mathbf{2}}$ \\
\hline Knowledge about transmission & 3 & 1430 & 67.7 & $29.9-195.6$ & $<0.001$ & $99.7 \%$ \\
\hline Symptoms & 2 & 780 & 73.1 & $70-76.2$ & $<0.001$ & 0 \\
\hline Attitude about COVID-19 isolation & 1 & 327 & 97.9 & $96.3-99.4$ & - & - \\
\hline Perception about COVID-19 & 2 & 1103 & 44 & $22.4-110-4$ & $<0.001$ & $99.9 \%$ \\
\hline Hand hygiene can prevent COVID-19 & 1 & 327 & 92.7 & $89.8-95.5$ & - & - \\
\hline $\begin{array}{l}\text { Low Quality studies (<75\% } \\
\text { response rate) }\end{array}$ & & & & & \\
\hline General knowledge & 2 & 643 & 41.8 & $19.5-103.5$ & 0.004 & $99.6 \%$ \\
\hline Knowledge about transmission & 5 & 9662 & 77.1 & $5.0-104.2$ & $<0.001$ & $99.9 \%$ \\
\hline Symptoms & 7 & 10,954 & 80.5 & $69.5-91.5$ & $<0.001$ & $99.6 \%$ \\
\hline Attitude about COVID-19 isolation & 1 & 662 & 95.9 & $94.4-97.4$ & - & - \\
\hline Hand hygiene & 4 & 2450 & 81.6 & $71.3-92$ & $<0.001$ & 98.7 \\
\hline Perception about COVID-19 & 7 & 6014 & 46.2 & $8.6-83-7$ & $<0.001$ & $99.9 \%$ \\
\hline $\begin{array}{l}\text { Practice about COVID-19, wearing } \\
\text { mask }\end{array}$ & 5 & 11,781 & 76.8 & $66.3-87.4$ & $<0.001$ & $99.8 \%$ \\
\hline Avoiding crowded areas & 5 & 11,010 & 89.3 & $83.9-94.8$ & $<0.001$ & $99.2 \%$ \\
\hline
\end{tabular}


medRxiv preprint doi: https://doi.org/10.1101/2020.06.24.20138891; this version posted June 24,2020 . The copyright holder for this preprint (which was not certified by peer review) is the author/funder, who has granted medRxiv a license to display the preprint in perpetuity.

It is made available under a CC-BY-NC-ND 4.0 International license .

Table 4: Study quality assessment of included studies that evaluated the knowledge, attitude, perception, and practice towards COVID-19

\begin{tabular}{|c|c|c|c|c|c|c|c|c|c|}
\hline Study & $\begin{array}{l}\text { Was the } \\
\text { sample } \\
\text { represent } \\
\text { ative } \\
\text { of the } \\
\text { target } \\
\text { populatio } \\
\text { n? }\end{array}$ & $\begin{array}{l}\text { Were } \\
\text { study } \\
\text { participa } \\
\text { nts } \\
\text { recruited } \\
\text { in an } \\
\text { appropria } \\
\text { te way? }\end{array}$ & $\begin{array}{l}\text { Was } \\
\text { the } \\
\text { sample } \\
\text { size } \\
\text { adequat } \\
\text { e? }\end{array}$ & $\begin{array}{l}\text { Were } \\
\text { the } \\
\text { study } \\
\text { subject } \\
\mathrm{s} \text { and } \\
\text { the } \\
\text { setting } \\
\text { describ } \\
\text { ed in } \\
\text { detail? }\end{array}$ & $\begin{array}{l}\text { Was the } \\
\text { data } \\
\text { analysis } \\
\text { conducted } \\
\text { with } \\
\text { sufficient } \\
\text { coverage } \\
\text { of the } \\
\text { identified } \\
\text { sample? }\end{array}$ & $\begin{array}{l}\text { Were } \\
\text { objective, } \\
\text { standard } \\
\text { criteria used } \\
\text { for the } \\
\text { measureme } \\
\text { nt of the } \\
\text { condition? }\end{array}$ & $\begin{array}{l}\text { Was the } \\
\text { condition } \\
\text { measured } \\
\text { reliably? }\end{array}$ & $\begin{array}{l}\text { Was there } \\
\text { appropriate } \\
\text { statistical } \\
\text { analysis? }\end{array}$ & $\begin{array}{l}\text { Are all the } \\
\text { important } \\
\text { confounding } \\
\text { factors/subgr } \\
\text { oups/differen } \\
\text { ces identified } \\
\text { and } \\
\text { accounted } \\
\text { for? }\end{array}$ \\
\hline Bhagavathula et al & Yes & Yes & $\begin{array}{l}\text { Not } \\
\text { clear }\end{array}$ & Yes & Yes & No & Yes & Yes & No \\
\hline Ahmed et al & Yes & No & $\begin{array}{l}\text { Not } \\
\text { clear }\end{array}$ & Yes & Yes & No & Yes & No & No \\
\hline Nemati et al & Yes & No & $\begin{array}{l}\text { Not } \\
\text { clear }\end{array}$ & Yes & Yes & No & No & No & No \\
\hline Giao et al & Yes & Yes & $\begin{array}{l}\text { Not } \\
\text { clear }\end{array}$ & Yes & Yes & No & No & Yes & No \\
\hline Clements & No & No & $\begin{array}{l}\text { Not } \\
\text { clear }\end{array}$ & Yes & Yes & No & No & Yes & No \\
\hline Zhong et al & No & No & $\begin{array}{l}\text { Not } \\
\text { clear }\end{array}$ & Yes & Yes & No & No & Yes & No \\
\hline Shi et al & Yes & No & $\begin{array}{l}\text { Not } \\
\text { clear }\end{array}$ & Yes & Yes & No & No & Yes & No \\
\hline Taghrir et al & Yes & No & Yes & Yes & Yes & No & Yes & Yes & No \\
\hline Roy et al & No & No & $\begin{array}{l}\text { Not } \\
\text { clear }\end{array}$ & No & Yes & No & No & No & No \\
\hline Li et al & No & Yes & $\begin{array}{l}\text { Not } \\
\text { clear }\end{array}$ & Yes & Yes & No & No & Yes & No \\
\hline Kang et al & Yes & No & $\begin{array}{l}\text { Not } \\
\text { clear }\end{array}$ & Yes & Yes & No & Yes & Yes & No \\
\hline Geldsetzer et al & No & No & $\begin{array}{l}\text { Not } \\
\text { clear }\end{array}$ & Yes & No & No & No & No & No \\
\hline Islam et al & No & No & $\begin{array}{l}\text { Not } \\
\text { clear }\end{array}$ & No & No & No & No & No & No \\
\hline Qian et al & No & Yes & $\begin{array}{l}\text { Not } \\
\text { clear }\end{array}$ & Yes & Yes & No & No & Yes & No \\
\hline Kwok et al & No & No & $\begin{array}{l}\text { Not } \\
\text { clear }\end{array}$ & Yes & Yes & No & No & Yes & No \\
\hline Dost et al & Yes & No & Yes & Yes & Yes & No & No & Yes & No \\
\hline Khader et al & Yes & Yes & $\begin{array}{l}\text { Not } \\
\text { clear }\end{array}$ & Yes & Yes & No & No & No & No \\
\hline $\begin{array}{c}\text { Mohd Hanafiah et } \\
\text { al }\end{array}$ & No & No & $\begin{array}{l}\text { Not } \\
\text { clear }\end{array}$ & Yes & Yes & No & No & Yes & No \\
\hline Wolf et al & Yes & No & $\begin{array}{l}\text { Not } \\
\text { clear }\end{array}$ & Yes & Yes & No & No & No & No \\
\hline
\end{tabular}

Abbreviation: COVID-19; Coronvirus disease 2019 
medRxiv preprint doi: https://doi.org/10.1101/2020.06.24.20138891; this version posted June 24, 2020. The copyright holder for this preprint (which was not certified by peer review) is the author/funder, who has granted medRxiv a license to display the preprint in perpetuity.

\section{It is made available under a CC-BY-NC-ND 4.0 International license .}

\section{Table 5: Risk of bias}

\begin{tabular}{|l|c|c|c|c|}
\hline & \multicolumn{2}{|c|}{ Egger test } & \multicolumn{2}{c|}{ Begg test } \\
\hline COVID-19-related & $t$-value & P-value & $z$-value & 0.072 \\
\hline Transmission & -2.81 & $\mathbf{0 . 0 3}$ & 1.80 & 0.251 \\
\hline Symptoms & -2.73 & $\mathbf{0 . 0 2 9}$ & 1.15 & 0.73 \\
\hline Perceptions & 1.21 & 0.266 & 0.83 & 0.308 \\
\hline Avoiding crowds & -1.68 & 0.234 & 1.02 & 0.089 \\
\hline Hand hygiene & -3.72 & 0.061 & 1.70 & 0.734 \\
\hline Wearing face masks & -2.27 & 0.151 & 0.34 & \\
\hline
\end{tabular}


medRxiv preprint doi: https://doi.org/10.1101/2020.06.24.20138891; this version posted June 24, 2020. The copyright holder for this preprint (which was not certified by peer review) is the author/funder, who has granted medRxiv a license to display the preprint in perpetuity.

\section{It is made available under a CC-BY-NC-ND 4.0 International license .}
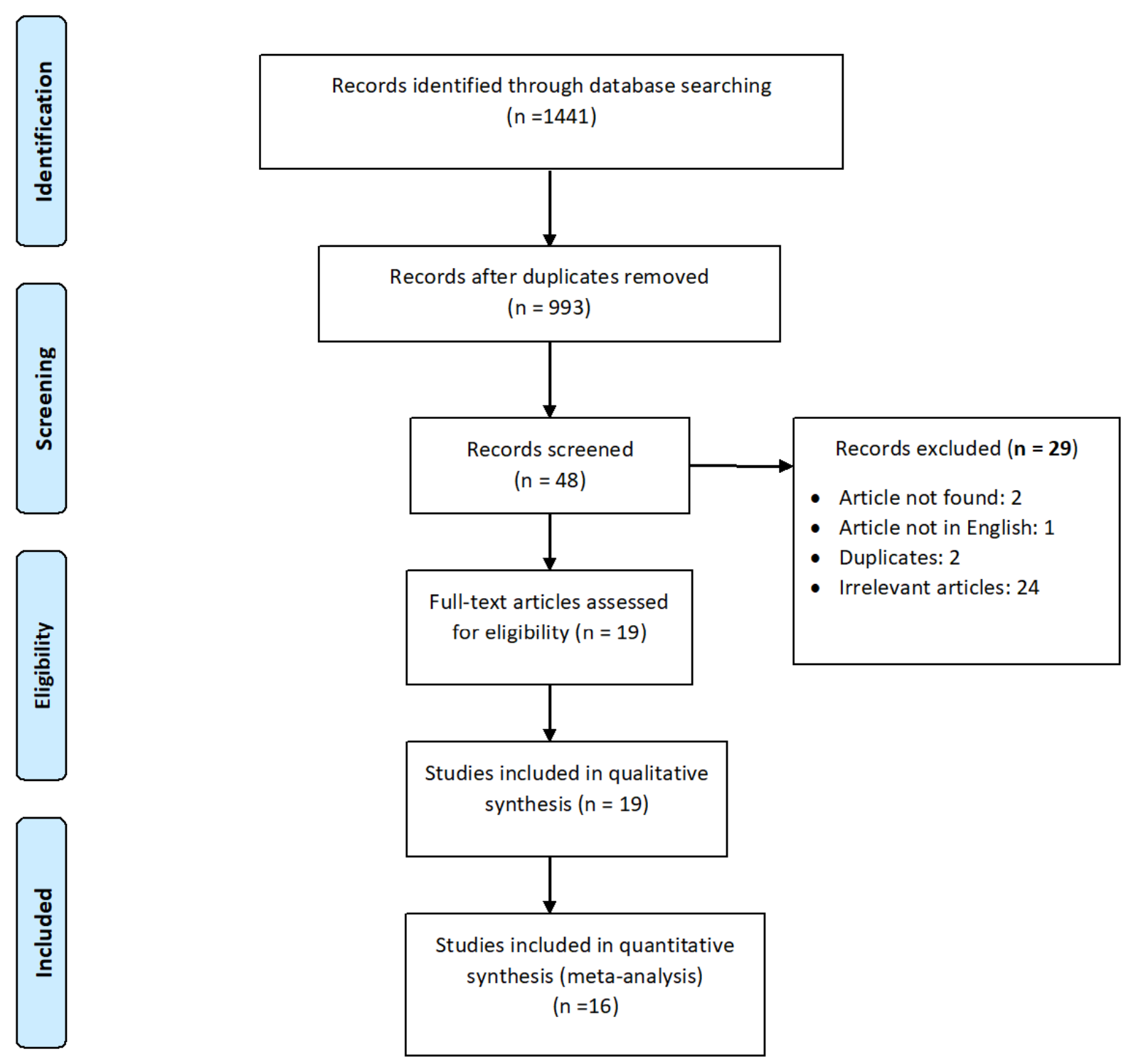

Figure 1: Flow of information through different phases of the systematic review 
medRxiv preprint doi: https://doi.org/10.1101/2020.06.24.20138891; this version posted June 24, 2020. The copyright holder for this preprint (which was not certified by peer review) is the author/funder, who has granted medRxiv a license to display the preprint in perpetuity.

It is made available under a CC-BY-NC-ND 4.0 International license.

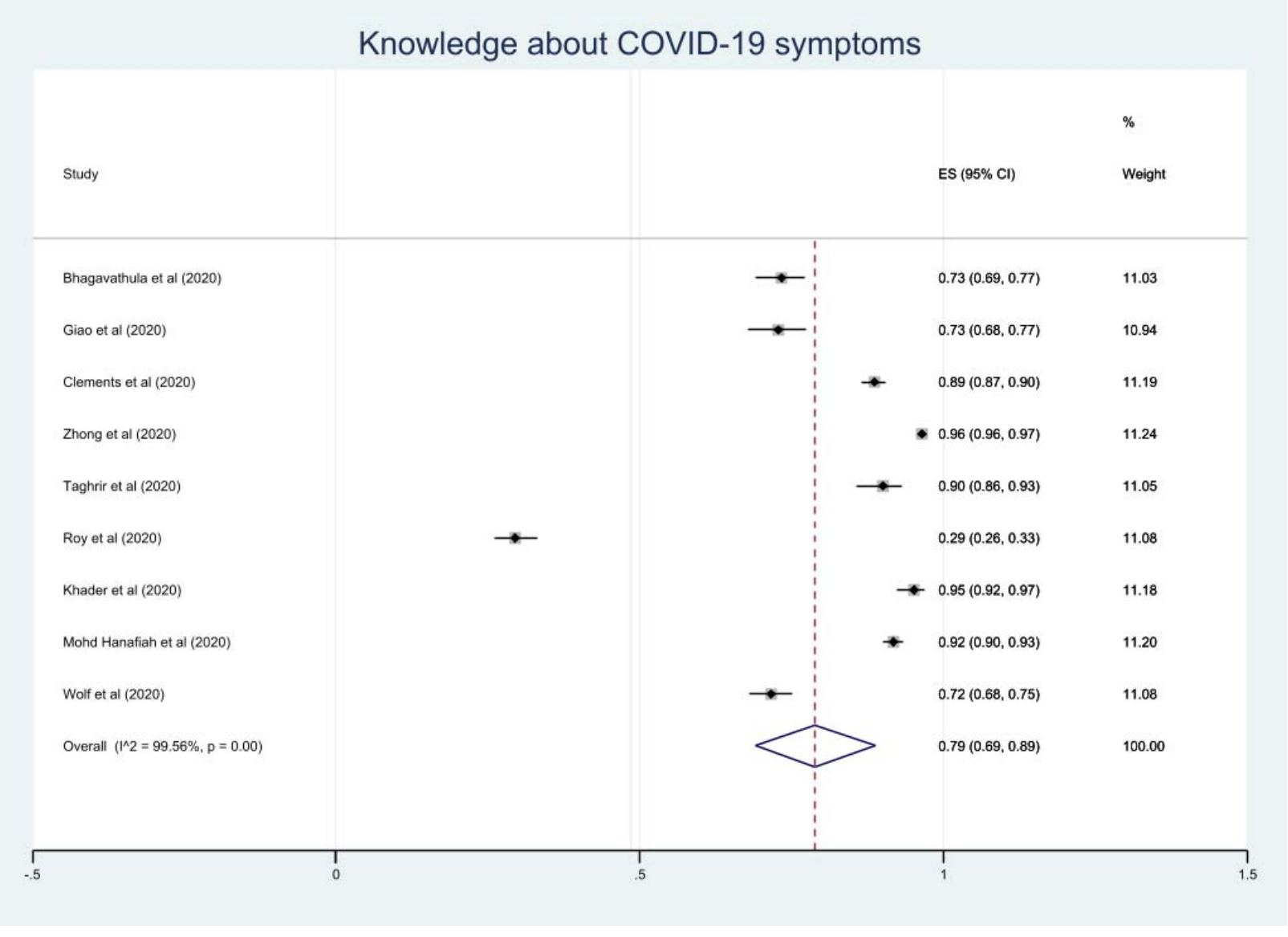

Figure 2: Knowledge about COVID-19-related symptoms 
medRxiv preprint doi: https://doi.org/10.1101/2020.06.24.20138891; this version posted June 24, 2020. The copyright holder for this preprint (which was not certified by peer review) is the author/funder, who has granted medRxiv a license to display the preprint in perpetuity.

\section{It is made available under a CC-BY-NC-ND 4.0 International license .}

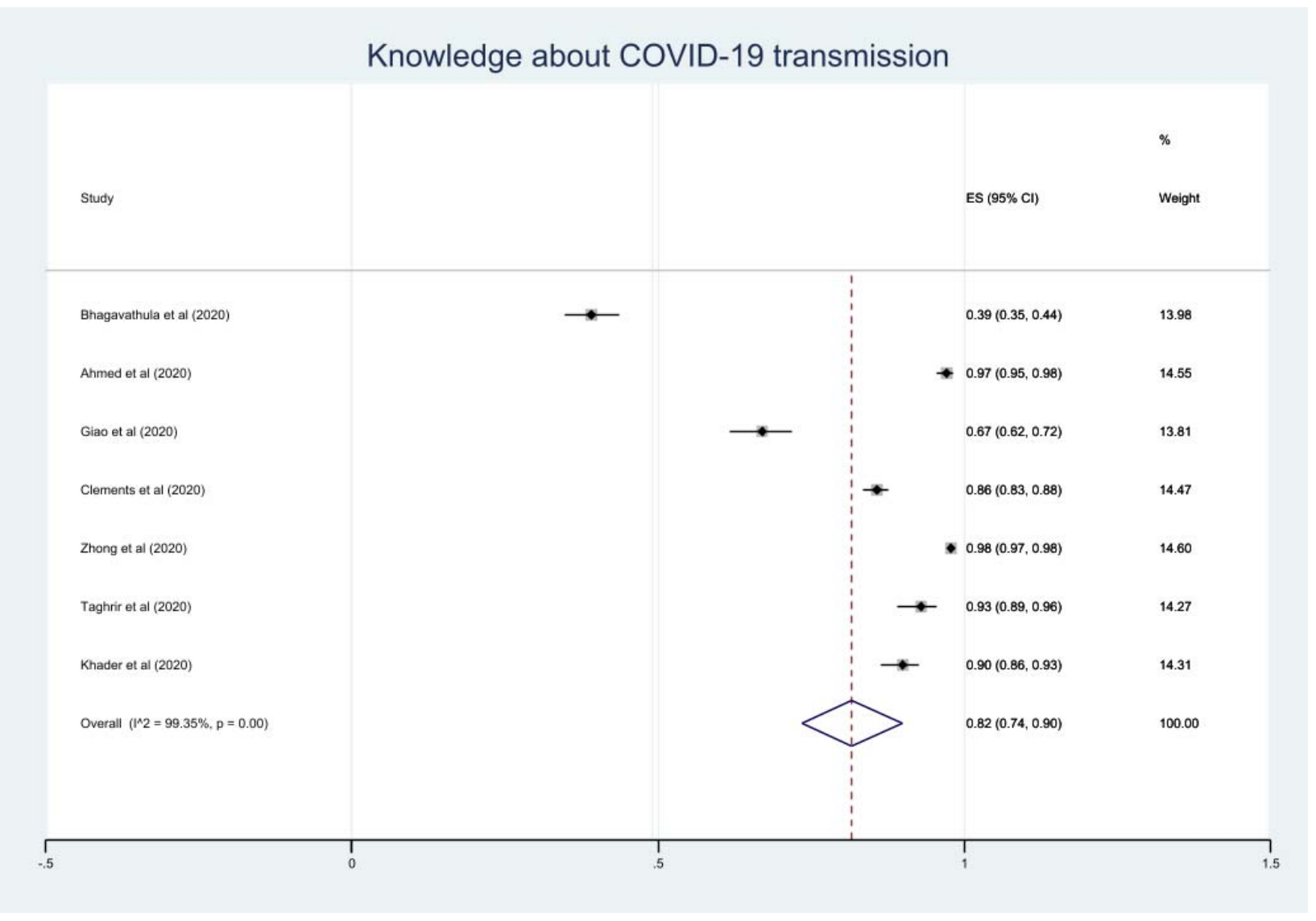

Figure 3: Knowledge about COVID-19 transmission 
medRxiv preprint doi: https://doi.org/10.1101/2020.06.24.20138891; this version posted June 24, 2020. The copyright holder for this preprint (which was not certified by peer review) is the author/funder, who has granted medRxiv a license to display the preprint in perpetuity.

It is made available under a CC-BY-NC-ND 4.0 International license.

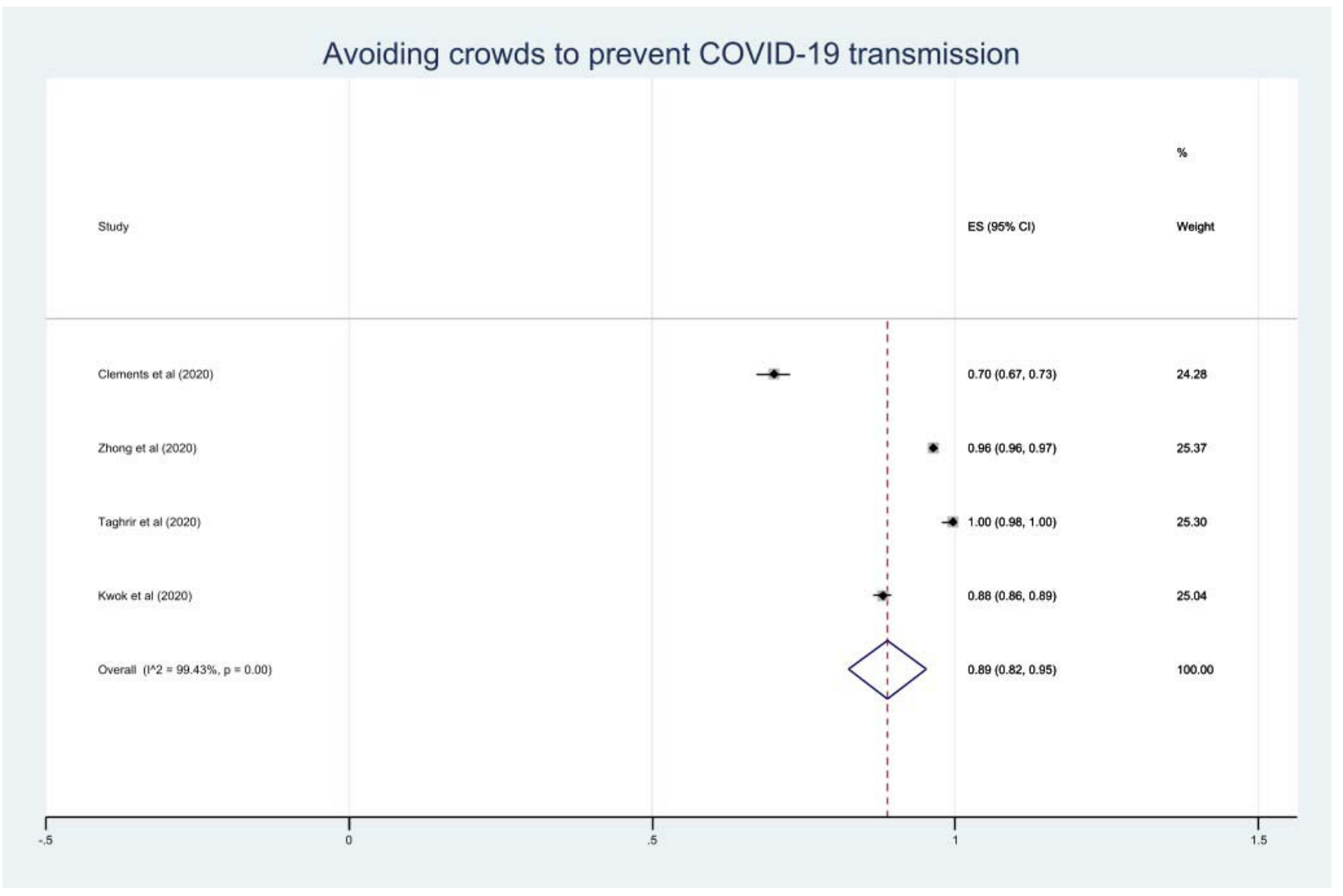

Figure 4: Attitude: Avoid crowded areas to prevent COVID-19 transmission 
medRxiv preprint doi: https://doi.org/10.1101/2020.06.24.20138891; this version posted June 24, 2020. The copyright holder for this preprint (which was not certified by peer review) is the author/funder, who has granted medRxiv a license to display the preprint in perpetuity.

\section{It is made available under a CC-BY-NC-ND 4.0 International license .}

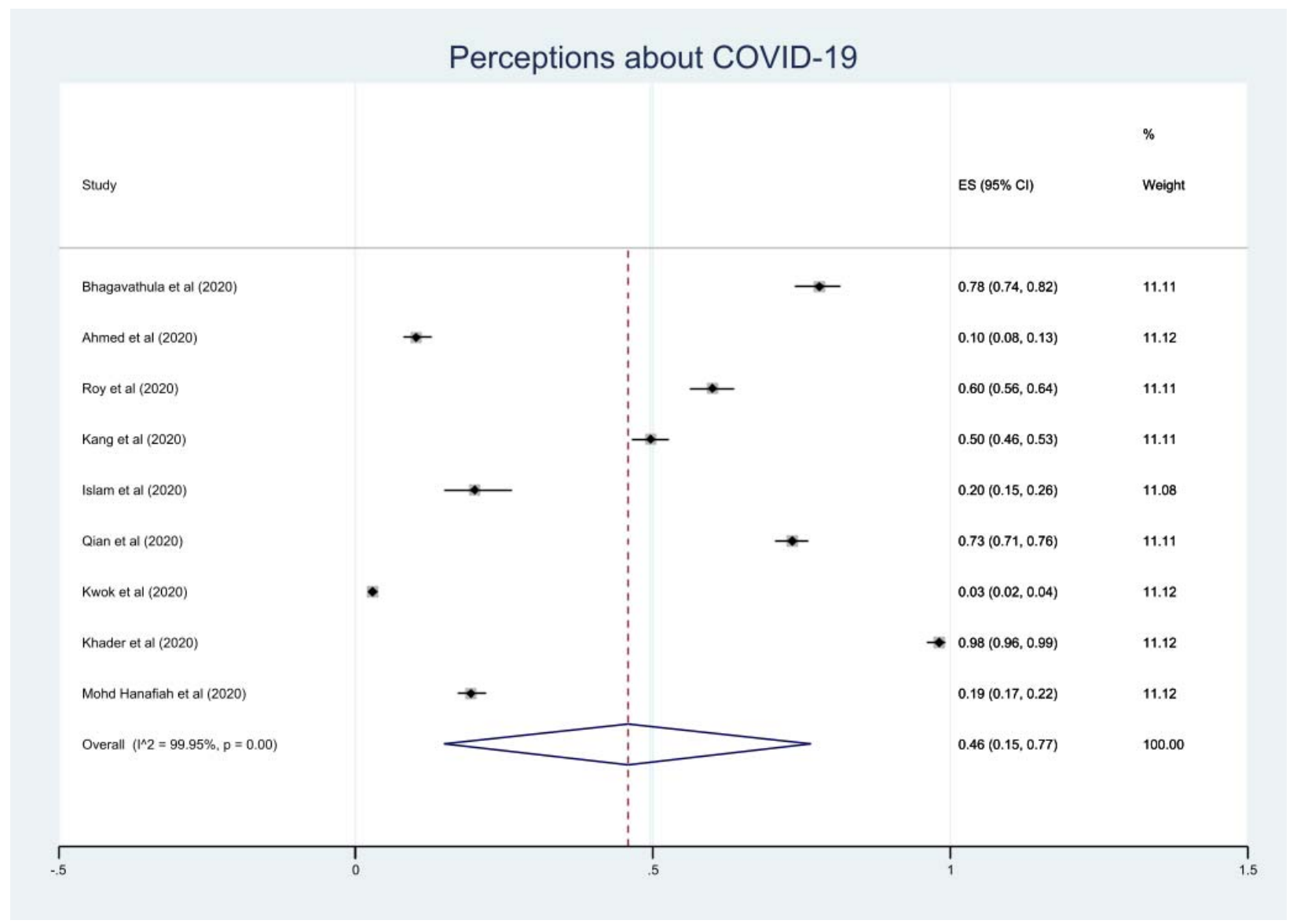

Figure 5: Perceptions about COVID-19 
medRxiv preprint doi: https://doi.org/10.1101/2020.06.24.20138891; this version posted June 24, 2020. The copyright holder for this preprint (which was not certified by peer review) is the author/funder, who has granted medRxiv a license to display the preprint in perpetuity.

It is made available under a CC-BY-NC-ND 4.0 International license.

Wearing facemask to prevent COVID-19 transmission

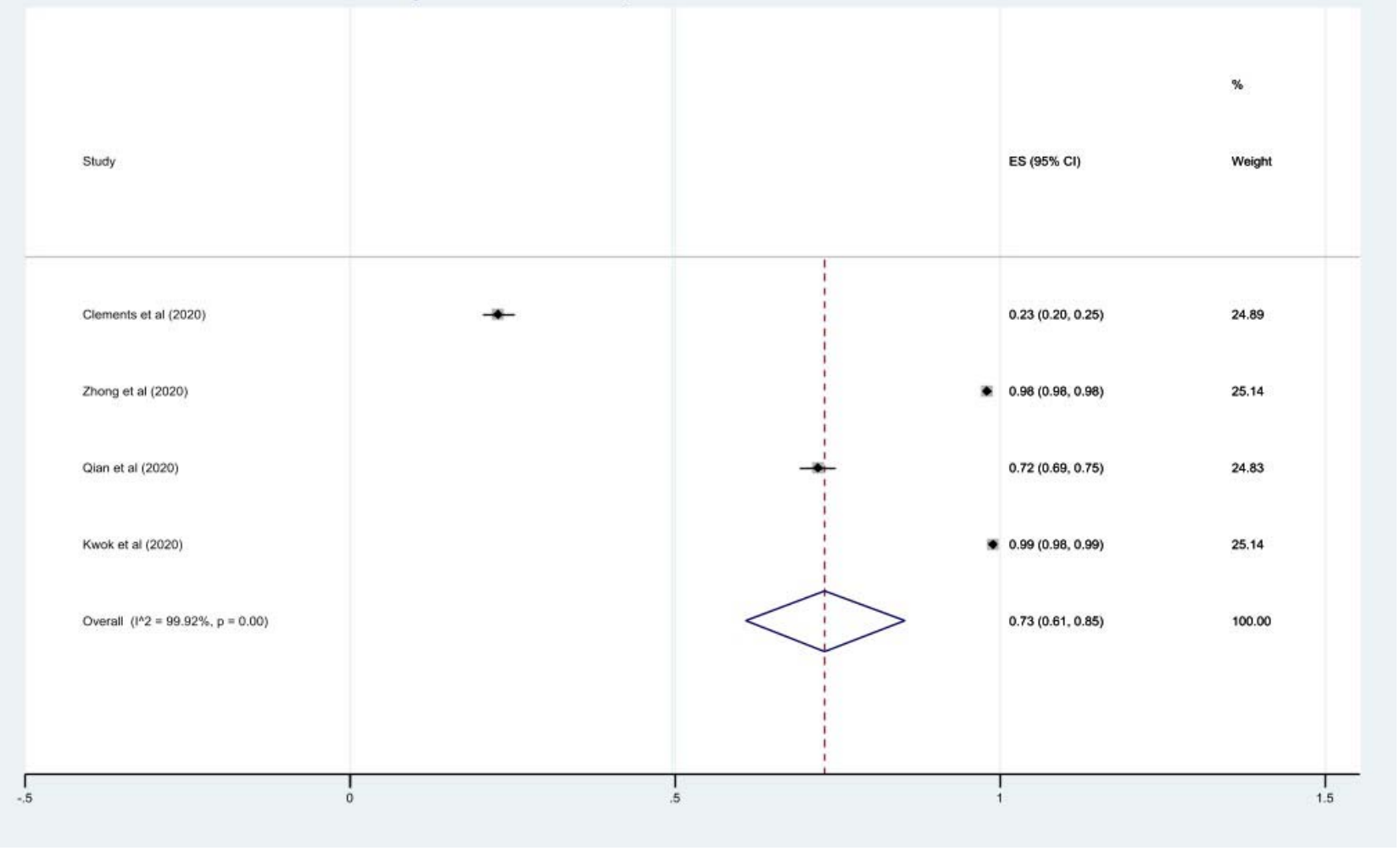

Figure 6: Practice: Wearing face mask to prevent COVID-19 transmission 
medRxiv preprint doi: https://doi.org/10.1101/2020.06.24.20138891; this version posted June 24, 2020. The copyright holder for this preprint (which was not certified by peer review) is the author/funder, who has granted medRxiv a license to display the preprint in perpetuity.

It is made available under a CC-BY-NC-ND 4.0 International license.

Hand hygiene to prevent COVID-19 transmission

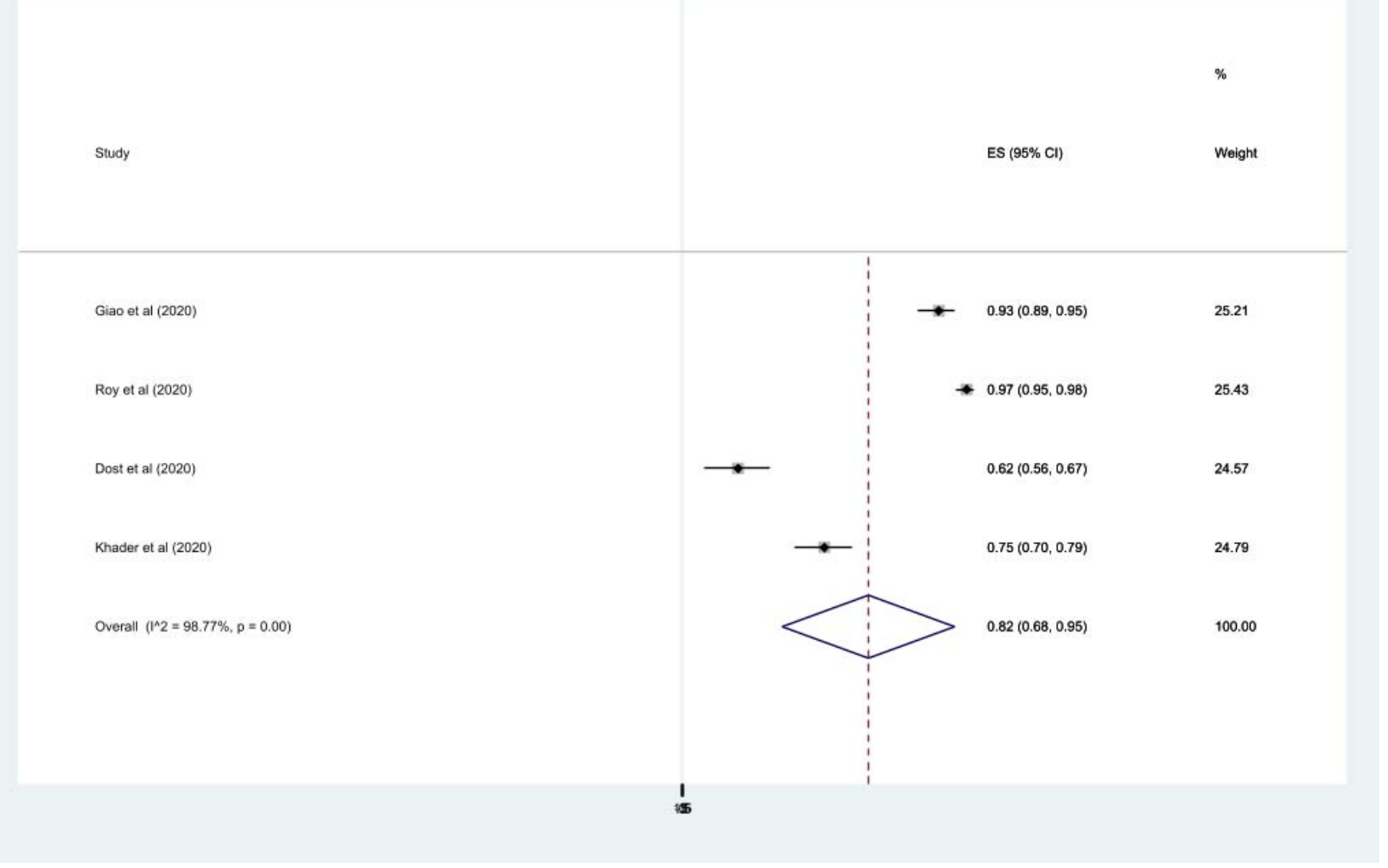

Figure 7: Practice: Hand hygiene practices to prevent COVID-19 transmission 